\title{
Studi Potensi Energi Listrik Tenaga Gelombang Laut Sistem Oscillating Water Column (OWC) di Perairan Pesisir Kalimantan Barat
}

Lelly Erlita Safitria ${ }^{a}$ Muh. Ishak Jumaranga*, Apriansyah ${ }^{b}$

\author{
aProgram Studi Fisika Jurusan Fisika, FMIPA Universitas Tanjungpura \\ bProgram Studi Ilmu Kelautan Jurusan Ilmu Kelautan, FMIPA Universitas Tanjungpura \\ Jalan Prof. Dr. H. Hadari Nawawi, Pontianak, Indonesia \\ *Email : ishakjumarang@physics.untan.ac.id
}

\begin{abstract}
Abstrak
Telah dilakukan penelitian untuk menghitung potensi energi listrik tenaga gelombang laut sistem Oscillating Water Column (OWC) di perairan pesisir Kalimantan Barat. Penelitian dilakukan pada 15 titik lokasi di perairan pesisir Kalimantan Barat. Penelitian ini menggunakan data kecepatan angin tahun 2006 s.d. 2014 untuk menentukan nilai tinggi signifikan dan periode gelombang menggunakan metode Wilson. Analisis daya listrik dilakukan pada empat kondisi musim yang ada di Indonesia, yaitu musim barat, peralihan I, musim timur dan peralihan II. Rata-rata daya listrik yang dihasilkan untuk musim barat berkisar 831,53 s.d. 229.404,42 Watt, untuk peralihan I berkisar 161,35 s.d. 22.585,14 Watt. Sedangkan untuk musim timur berkisar 301,35 s.d. 265.620,97 Watt dan untuk peralihan II berkisar 139,64 s.d. 164.495,99 Watt. Daya listrik tertinggi berada di Pantai Pulau Karimata, Kab. Kayong Utara pada musim barat dengan nilai sebesar 831.370,47 Watt. Sedangkan daya listrik terendah berada di Pantai Pulau Datok, Kab. Kayong Utara pada kondisi peralihan I dengan nilai sebesar 0,007 Watt. Berdasarkan daya listrik yang telah dikaji, lokasi yang berpotensi besar menghasilkan daya listrik adalah Pantai Temajuk Kab. Sambas, Pantai Pulau Karimata Kab. Kayong Utara dan Pantai Pulau Bawal Kab. Ketapang.
\end{abstract}

Kata Kunci : Energi Listrik, Gelombang Laut, Metode Wilson, Sistem OWC

\section{Latar Belakang}

Indonesia memiliki kebutuhan energi listrik yang semakin meningkat setiap tahunnya seiring dengan pertambahan penduduk dan pertumbuhan ekonomi. Berdasarkan hasil proyeksi kebutuhan listrik Perusahaan Listrik Negara (PLN) dari tahun 2003 s.d. 2020 terlihat bahwa selama kurun waktu tersebut rerata kebutuhan listrik di Indonesia tumbuh sebesar $6,5 \%$ per tahun[1]. Peningkatan kebutuhan listrik tersebut membuat masyarakat mencari sumber energi alternatif agar kebutuhan energi listrik dapat tetap terpenuhi. Salah satu sumber energi alternatif yang bisa dikembangkan di Indonesia yaitu sumber energi listrik dari tenaga gelombang laut.

Balai Pengkajian Dinamika Pantai Universitas Gadjah Mada (BPDP-UGM) bekerjasama dengan Badan Pengkajian dan Penerapan Teknologi (BPPT) telah berhasil membangun prototype pertama Pembangkit Listrik Tenaga Gelombang Laut di Indonesia dengan sistem Oscillating Water Column (PLTGLOWC). PLTGL OWC ini dibangun di Pantai Baron, Yogyakarta.

Penelitian sebelumnya telah dilakukan dengan menggunakan data sekunder kecepatan dan arah angin permukaan periode harian dan musiman di perairan pantai Bengkulu menggunakan metode Sverdrup Munck Bretschneider (SMB) untuk mendapatkan potensi energi listrik tenaga gelombang laut sistem OWC selama kurun waktu 2003 s.d. 2012[2]. Berdasarkan hal tersebut di atas, penulis tertarik untuk mengkaji potensi energi listrik di perairan pesisir Kalimantan Barat dengan sistem OWC dan peramalan gelombang menggunakan metode Wilson selama kurun waktu 2006 s.d. 2014.

Teknologi OWC sangat cocok dibangun di daerah dengan topografi dasar laut yang landai dan memiliki ketinggian gelombang laut yang konstan serta tidak memerlukan daerah konstruksi yang luas[3]. Berdasarkan kriteria tersebut, teknologi sistem OWC dapat digunakan di perairan pesisir Kalimantan Barat dikarenakan kondisi topografi dasar lautnya yang landai serta ketinggian gelombang laut yang konstan. Diharapkan penelitian ini dapat dijadikan pertimbangan Pemerintah Daerah Kalimantan Barat untuk pembuatan kebijakan pembangunan PLTGL di Kalimantan Barat.

\section{Metodologi}

\subsection{Lokasi dan Waktu Penelitian}

Penelitian ini dilakukan di 15 titik di perairan pesisir Kalimantan Barat seperti terlihat pada Gambar 1. 


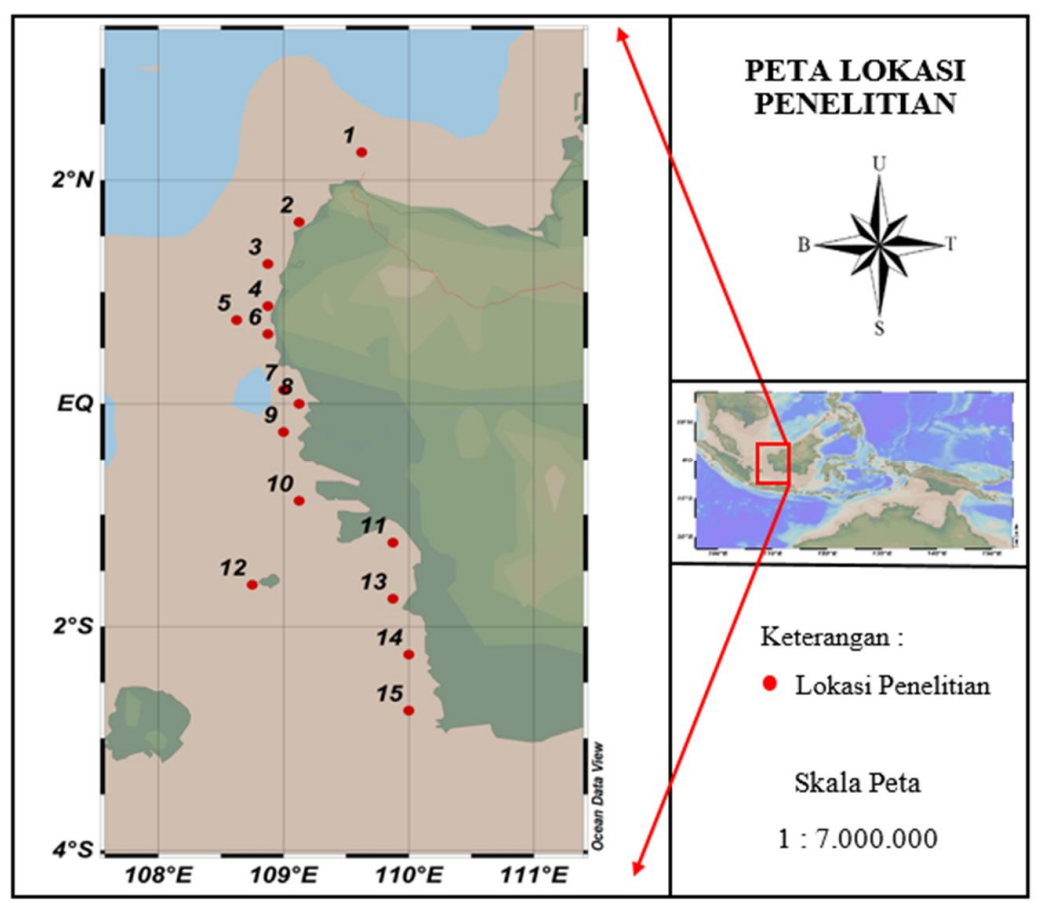

Gambar 1. Peta Lokasi Penelitian

\subsection{Sumber Data}

Penelitian ini menggunakan data kecepatan angin bulanan dalam arah $\mathrm{u}$ dan $\mathrm{v}$ dengan ketinggian 10 meter di atas permukaan laut dari tahun 2006 s.d. 2014 yang diperoleh dari European Center for Medium Range Forecast ECMWF[4].

Selain itu, diperlukan data massa jenis air laut untuk menghitung daya listrik sistem OWC di perairan pesisir Kalimantan Barat. Nilai massa jenis air laut didapatkan dari data Conductivity, Temperature and Depth (CTD) untuk Selat Karimata pada bulan April 2014. Nilai massa jenis air laut cenderung konstan untuk kedalaman kurang dari 100 meter dan untuk suatu perairan tertentu. Sehingga data pada bulan April 2014 di Selat Karimata tersebut dapat digunakan untuk massa jenis di perairan pesisir Kalimantan Barat. Perhitungan nilai massa jenis air laut menggunakan data CTD didapatkan dengan menggunakan Persamaan Keadaan Air Laut.

\subsection{Langkah-langkah Penelitian}

\subsubsection{Perhitungan Resultan Kecepatan dan} Arah Angin

Nilai resultan angin didapatkan dari nilai komponen $\mathrm{u}$ dan $\mathrm{v}$ kecepatan angin. Nilai u pada kecepatan angin adalah nilai kecepatan angin dalam arah vektor $\mathrm{x}$ atau dalam arah timur barat atau yang biasa disebut dengan angin zonal, sedangkan nilai $\mathrm{v}$ adalah nilai kecepatan angin dalam arah vektor y atau dalam arah utara - selatan atau yang biasa disebut dengan angin meridiornal. Nilai kecepatan resultan angin didapat dari persamaan :

$$
U=\sqrt{u^{2}+v^{2}}
$$

$U$ adalah resultan kecepatan angin $(\mathrm{m} / \mathrm{s})$, sedangkan $u$ dan $v$ masing-masing adalah kecepatan angin dalam arah vektor $\mathrm{x}$ dan $\mathrm{y}$ dalam satuan $\mathrm{m} / \mathrm{s}$.

Arah angin yang digunakan adalah arah angin dominan di tiap titik lokasi penelitian. Pengelompokan arah angin dominan berdasarkan delapan arah mata angin menggunakan diagram mawar angin. Adapun persamaan yang digunakan untuk menentukan arah kecepatan angin yaitu :

$$
\theta=\arctan \frac{v}{u}
$$

dengan $\theta$ merupakan arah angin yang berhembus, $u$ merupakan kecepatan angin dalam arah vektor $\mathrm{x}(\mathrm{m} / \mathrm{s})$ dan $v$ adalah kecepatan angin dalam arah vektor $\mathrm{y}(\mathrm{m} / \mathrm{s})$.

\subsubsection{Penentuan Nilai Tegangan Angin}

Kecepatan angin dipengaruhi oleh faktor tegangan angin, adapun persamaan untuk menghitung nilai tegangan angin adalah[5]:

$$
U_{A}=0,71 \times U^{1,23}
$$


dengan $U_{\text {A }}$ adalah tegangan angin $(\mathrm{m} / \mathrm{s})$ dan $U$ adalah resultan kecepatan angin $(\mathrm{m} / \mathrm{s})$.

\subsubsection{Penentuan Fetch Gelombang}

Fetch merupakan jarak pembentukan gelombang yang diasumsikan memiliki kecepatan dan arah angin yang relatif konstan hingga menuju ke daratan. Panjang fetch dapat diukur manual menggunakan aplikasi peta Google Earth. Panjang fetch dihitung berdasarkan rentang $22,5^{0}$ samping kiri arah utama hingga 22,50 samping kanan arah utama. Besar interval pada tiap panjang fetch yang diukur adalah sebesar $5^{0}$. Persamaan fetch dapat ditulis sebagai berikut[5]:

$$
F=\frac{\sum_{i=1}^{k} F_{i} \cos \alpha_{i}}{\sum_{i=1}^{k} \cos \alpha_{i}}
$$

dengan $F_{i}$ adalah panjang fetch ke-i $(\mathrm{m}), \alpha_{i}$ adalah sudut pengukuran fetch ke-i ( $\left.{ }^{\circ}\right)$, i adalah nomor pengukuran fetch dan $\mathrm{k}$ adalah jumlah pengukuran fetch.

\subsubsection{Peramalan Gelombang dengan Metode Wilson}

Peramalan gelombang digunakan untuk mencari nilai tinggi signifikan gelombang laut dan periode gelombang laut. Tinggi gelombang laut merupakan jarak dari puncak ke lembah gelombang, sedangkan periode gelombang laut merupakan waktu yang diperlukan untuk satu panjang gelombang yang merambat melewati satu titik tertentu. Karakteristik ombak yang menuju ke tepi pantai pada saat angin berhembus dapat diprediksi dengan metode Wilson[6]. Adapun persamaan yang digunakan pada metode Wilson sebagai berikut :

$$
\begin{aligned}
& H s=\frac{0,3}{g}\left[1-\left\{1+0,004\left(\frac{g F}{U^{2}}\right)^{\frac{1}{2}}\right\}^{-2}\right] U^{2} \\
& T=6,23 \times 10^{-2}\left(U_{A} F\right)^{1 / 3}
\end{aligned}
$$

dengan $U$ adalah kecepatan angin $(\mathrm{m} / \mathrm{s}), F$ merupakan panjang fetch gelombang $(\mathrm{m}), \quad H s$ adalah tinggi signifikan gelombang laut (m), $T$ adalah periode gelombang laut (s), $U_{A}$ merupakan tegangan angin $(\mathrm{m} / \mathrm{s})$ dan $g$ adalah percepatan gravitasi bumi $\left(9,81 \mathrm{~m} / \mathrm{s}^{2}\right)$.

\subsubsection{Perhitungan Daya Listrik Sistem OWC}

PLTGL sistem OWC membangkitkan listrik dari naik turunnya air laut akibat gelombang laut yang masuk kedalam sebuah kolom osilasi yang berlubang. Naik turunnya air laut ini akan mengakibatkan keluar masuknya udara di lubang bagian atas kolom dan tekanan yang dihasilkan dari naik turunnya air laut dalam kolom tersebut akan menggerakkan turbin (Gambar 2).

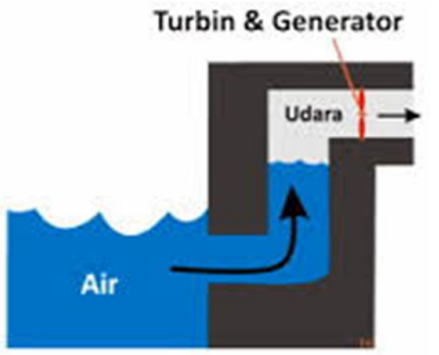

Gambar 2. Skema Sistem OWC[7]

Tenaga mekanik yang dihasilkan dari sistem-sistem tersebut akan mengaktifkan generator secara langsung. PLTGL sistem OWC merupakan sistem dengan konstruksi yang terdiri dari dua komponen utama, yaitu ruang udara serta ruang turbin udara dan generator. Proses pengubahan dari energi gerak gelombang kepada energi potensial berlangsung secara isothermis. Pendekatan ini dipilih karena dalam proses ini dianggap tidak terjadi peningkatan temperatur yang berarti.

Besarnya energi potensial dari gelombang laut dapat dihitung dengan persamaan sebagai berikut [8] :

(7)

$$
E_{P}=m g \frac{y(x, t)}{2}
$$

dengan $E_{P}$ adalah energi potensial gelombang (Joule), $m$ adalah massa air laut yang masuk ke ruang sistem OWC $(\mathrm{kg})$ dan $g$ merupakan percepatan gravitasi bumi $\left(9,81 \mathrm{~m} / \mathrm{s}^{2}\right)$.

Bentuk persamaan pada gelombang yaitu :

$$
y(x, t)=A \sin (k x-\omega t)
$$

Nilai energi potensial tiap panjang gelombang didapatkan dengan persamaan sebagai berikut :

$$
E_{P}=\int_{0}^{\lambda} E_{P} d x
$$

Sehingga didapatkan persamaan energi potensial tiap panjang gelombang yaitu :

$$
E_{P}=\frac{1}{4} \rho w g A^{2} \lambda
$$

Energi potensial gelombang yang telah lewat dari satu periode gelombang memiliki nilai yang sama dengan energi kinetiknya. Sehingga energi kinetik gelombang dapat ditulis sebagai berikut : 


$$
E_{K}=\frac{1}{4} \rho w g A^{2} \lambda
$$

Energi gelombang adalah energi mekanik gelombang yang merupakan total dari energi potensial gelombang dan energi kinetik gelombang, sehingga :

$$
\begin{aligned}
& E_{M}=E_{P}+E_{K} \\
& E_{M}=\left(\frac{1}{4} \rho w g A^{2} \lambda\right)+\left(\frac{1}{4} \rho w g A^{2} \lambda\right) \\
& E_{M}=\frac{1}{2} \rho w g A^{2} \lambda
\end{aligned}
$$

Dari energi mekanik gelombang akan didapatkan nilai daya yang dihasilkan oleh gelombang dengan persamaan sebagai berikut :

$$
\begin{aligned}
& P=\frac{E_{M}}{T} \\
& P=\frac{\rho w g A^{2} \lambda}{2 T}
\end{aligned}
$$

dengan $\lambda=\frac{g}{2 \pi} T^{2}$ dan $A=\frac{h}{2}$ maka,

$$
P=\frac{1}{16 \pi} \rho w g^{2} h^{2} T
$$

dengan $P$ merupakan daya listrik (Watt), $w$ adalah lebar ruang (2,4 meter), $\rho$ merupakan massa jenis air laut $\left(\mathrm{kg} / \mathrm{m}^{3}\right), \quad g$ adalah percepatan gravitasi bumi $\left(9,81 \mathrm{~m} / \mathrm{s}^{2}\right), h$ adalah tinggi gelombang laut (m) dan $T$ adalah periode gelombang laut (detik).

Perhitungan daya listrik yang dihasilkan oleh gelombang laut dengan sistem OWC menggunakan spesifikasi prototype (lebar ruang 2,4 meter), sesuai prototype yang dioperasikan oleh BPDP UGM - BPPT di Pantai Baron, Yogyakarta, yang juga telah digunakan pada penelitian sebelumnya[9]. Penelitian ini dilakukan dengan mengabaikan nilai efisiensi alat sebesar 11,971 \%.

\subsection{Verifikasi Data Gelombang Metode Wilson \& Data Lapangan}

Metode untuk memprediksi data angin menjadi data gelombang perlu menggunakan data pembanding untuk melihat persentase kesalahan relatifnya. Data pembanding ini bisa didapatkan dengan menggunakan data pengukuran langsung. Data pengukuran langsung yang dijadikan verifikasi pada penelitian ini yaitu menggunakan data penelitian yang berupa tinggi signifikan dan periode gelombang di perairan Pulau Lemukutan pada tanggal 1 s.d. 3 Oktober 2006[10]. Verifikasi data dilakukan pada tinggi signifikan gelombang dan periode gelombang yang dihasilkan dari metode Wilson terhadap pengukuran langsung dengan menggunakan persamaan sebagai berikut :

$$
K R=\left|\frac{X_{P}-X_{S}}{X_{P}}\right| 100 \%
$$

dengan $K R$ adalah kesalahan relatif (\%), $X_{P}$ adalah data pengukuran langsung dan $X_{S}$ adalah data pengolahan metode Wilson.

\subsection{Analisis Hasil}

Hasil dari penelitian ini akan ditinjau berdasarkan empat kondisi musim yang ada di Indonesia, yaitu musim barat, musim timur, peralihan I dan peralihan II. Potensi daya listrik yang dihasilkan akan berbeda pada tiap-tiap kondisi tersebut. Daya listrik yang dihasilkan dari gelombang laut pada perairan pesisir Kalimantan Barat di 15 lokasi memiliki daya listrik yang berbeda-beda pula. Hasil dari penelitian ini diharapkan akan dapat menunjukkan daerah mana yang lebih potensial dibandingkan dengan daerah-daerah lainnya.

\subsection{Diagram Alir Penelitian}

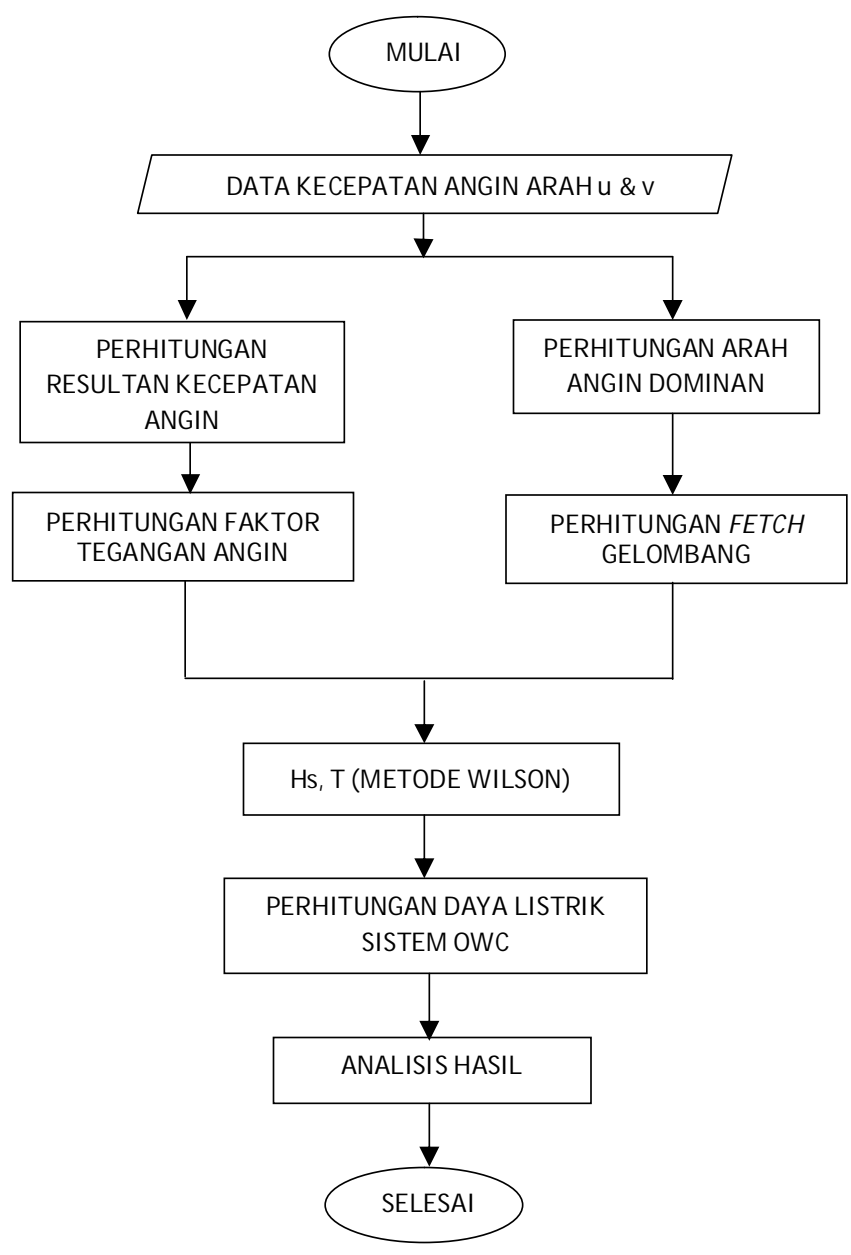

Gambar 3. Diagram Alir Penelitian 
3. Hasil dan Pembahasan

\subsection{Verifikasi Data Gelombang Metode Wilson} \& Data Lapangan

Verifikasi data dilakukan dengan menggunakan penelitian lapangan di Perairan Melano Barat Pulau Lemukutan, Kabupaten Bengkayang, Kalimantan Barat. Data lapangan meliputi data tinggi dan periode signifikan gelombang selama tiga hari dari tanggal 1 s.d. 3 Oktober 2006. Didapatkan nilai rata-rata tinggi signifikan gelombang selama tiga hari tersebut adalah 0,131 meter sedangkan rata-rata nilai periode gelombang selama tiga hari tersebut yaitu 5,658 detik. Penelitian lapangan tersebut dilakukan pada kondisi peralihan II yang terjadi pada bulan September hingga Nopember[10].

Perhitungan data citra satelit untuk mendapatkan nilai tinggi signifikan dan periode gelombang yaitu dengan menggunakan metode Wilson. Data citra satelit yang digunakan untuk diverifikasi terhadap data gelombang pengukuran lapangan tersebut yaitu data tinggi signifikan dan periode gelombang rata-rata bulan Oktober 2006. Digunakan nilai tinggi signifikan dan periode gelombang rata-rata satu bulan untuk analisis data citra satelit karena data kecepatan angin yang digunakan pada penelitian ini adalah data kecepatan angin rata-rata bulanan. Kondisi tinggi dan periode gelombang akan cenderung sama untuk satu bulan sebab gelombang yang dibangkitkan oleh angin pada waktu dan bulan yang sama mempunyai arah dan kecepatan angin yang relatif sama. Sehingga data lapangan tiga hari tersebut dapat mewakili data selama bulan Oktober 2006. Didapatkan nilai rata-rata tinggi signifikan dan periode gelombang selama bulan Oktober 2006 dengan menggunakan metode Wilson masing-masing yaitu 0,118 meter dan 5,669 detik.

Tabel 1. Perbandingan data gelombang metode Wilson dan data lapangan

\begin{tabular}{cccc}
\hline $\begin{array}{c}\text { Data } \\
\text { Gelombang }\end{array}$ & $\begin{array}{c}\text { Metode } \\
\text { Wilson }\end{array}$ & $\begin{array}{c}\text { Pengukuran } \\
\text { Lapangan }\end{array}$ & $\begin{array}{c}\text { Kesalahan } \\
\text { Relatif }\end{array}$ \\
\hline Hs (meter) & 0,118 & 0,131 & $9,92 \%$ \\
T (detik) & 5,669 & 5,658 & $0,19 \%$ \\
\hline
\end{tabular}

Tabel 1 menunjukkan perbandingan data pengolahan metode Wilson dan data lapangan, sehingga didapatkan nilai kesalahan relatif untuk data tinggi signifikan dan periode gelombang metode Wilson terhadap data lapangan masingmasing sebesar $9,92 \%$ dan $0,19 \%$.

\subsection{Daya Listrik Sistem OWC \\ 3.2.1 Rata-rata Daya Listrik Sistem OWC pada Musim Barat}

Arah angin dominan yang terjadi pada musim barat (Desember-Januari-Februari) di perairan pesisir Kalimantan Barat adalah angin barat laut hingga utara. Kecepatan angin yang bertiup pada musim barat di perairan pesisir Kalimantan Barat berkisar antara 1,688 s.d. $4,147 \mathrm{~m} / \mathrm{s}$. Nilai tinggi gelombang berkisar antara 0,069 s.d. 0,513 meter dan untuk periode gelombang berkisar antara 1,835 s.d. 10,520 detik. Kecepatan angin dan tinggi gelombang tertinggi berada di lokasi 15 (Pantai Pulau Bawal, Kab. Ketapang), kemudian kecepatan angin dan tinggi gelombang terendah berada di lokasi 11 (Pantai Pulau Datok, Kab. Kayong Utara) sedangkan untuk periode gelombang tertinggi terletak di lokasi 1 (Pantai Temajuk, Sungai Paloh, Kab. Sambas) dan selanjutnya lokasi 12 (Pantai Pulau Karimata, Kab. Kayong Utara), kemudian periode gelombang terendah di lokasi 11 (Pantai Pulau Datok, Kab. Kayong Utara).

Rata-rata daya listrik di perairan pesisir Kalimantan Barat pada musim barat berkisar antara 831,53 s.d. 229.404,42 Watt (Gambar 4) dengan rata-rata daya listrik tertinggi berada di lokasi 12 (Pantai Pulau Karimata, Kab. Kayong Utara) dan rata-rata daya listrik terendah di lokasi 11 (Pantai Pulau Datok, Kab. Kayong Utara).

Lokasi 12 memiliki rata-rata daya listrik tertinggi dibandingkan dengan 14 tempat lainnya dikarenakan kecepatan angin, tinggi dan periode gelombang yang berada di lokasi tersebut cukup tinggi. Besarnya nilai tinggi dan periode gelombang dipengaruhi oleh panjang fetch yang terbentuk. Semakin panjang fetch maka semakin besar nilai tinggi dan periode gelombang yang terbentuk. Lokasi 12 memiliki fetch yang panjang dikarenakan tidak ada pulau-pulau kecil yang menghalangi pembentukan fetch. Sedangkan rata-rata daya listrik terendah berada di lokasi 11, hal ini dikarenakan kecepatan angin, tinggi dan periode gelombang terendah berada di lokasi tersebut. Fetch yang terbentuk di lokasi 11 pendek dikarenakan banyak terhalang oleh daratan. 


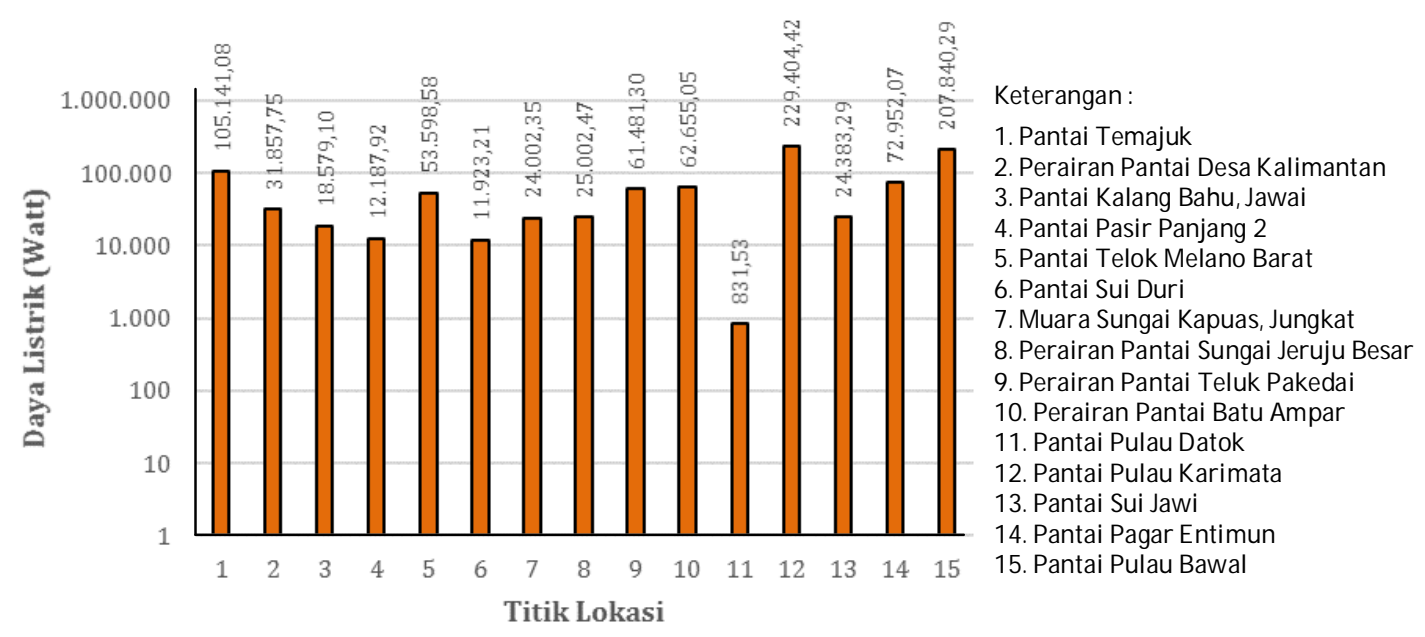

Gambar 4. Histogram rata-rata daya listrik musim barat

\subsubsection{Rata-rata Daya Listrik Sistem OWC pada Kondisi Peralihan I}

Arah angin dominan pada kondisi peralihan I (Maret-April-Mei) di perairan pesisir Kalimantan Barat bervariasi dan cenderung tidak teratur. Kecepatan angin yang bertiup pada kondisi peralihan I di perairan pesisir Kalimantan Barat berkisar antara 0,719 s.d. 2,332 $\mathrm{m} / \mathrm{s}$. Nilai tinggi gelombang berkisar antara 0,020 s.d. 0,177 meter dan untuk periode gelombang berkisar antara 1,218 s.d. 8,536 detik. Kecepatan angin dan tinggi gelombang tertinggi berada di lokasi 15 (Pantai Pulau Bawal, Kab. Ketapang) kemudian kecepatan angin terendah berada di lokasi 6 (Pantai Sui Duri, Kab. Bengkayang), sedangkan tinggi gelombang terendah berada di lokasi 6 (Pantai Sui Duri, Kab. Bengkayang) dan lokasi 7 (Muara Sungai Kapuas, Jungkat, Kab. Mempawah). Periode gelombang tertinggi terletak di lokasi 1 (Pantai Temajuk, Sungai Paloh, Kab. Sambas) dan periode gelombang terendah di lokasi 13 (Pantai Sui Jawi, Kab. Ketapang).
Rata-rata daya listrik di perairan pesisir Kalimantan Barat pada kondisi peralihan I berkisar antara 161,35 s.d. 22.585,14 Watt (Gambar 5) dengan rata-rata daya listrik tertinggi berada di lokasi 15 (Pantai Pulau Bawal, Kab. Ketapang) dan rata-rata daya listrik terendah di lokasi 11 (Pantai Pulau Datok, Kab. Kayong Utara).

Lokasi 15 memiliki rata-rata daya listrik tertinggi dibandingkan dengan 14 tempat lainnya dikarenakan kecepatan angin dan tinggi gelombang yang tertinggi berada di lokasi tersebut. Lokasi 15 memiliki fetch yang panjang dikarenakan tidak ada pulau-pulau kecil yang menghalangi pembentukan fetch karena berbatasan langsung dengan Laut Jawa, sehingga tinggi gelombang yang dihasilkan semakin besar. Kemudian rata-rata daya listrik terendah berada di lokasi 11, hal ini dikarenakan kecepatan angin, tinggi dan periode gelombang yang berada di lokasi tersebut cukup rendah. Fetch yang terbentuk di lokasi 11 pendek dikarenakan banyak terhalang oleh daratan.

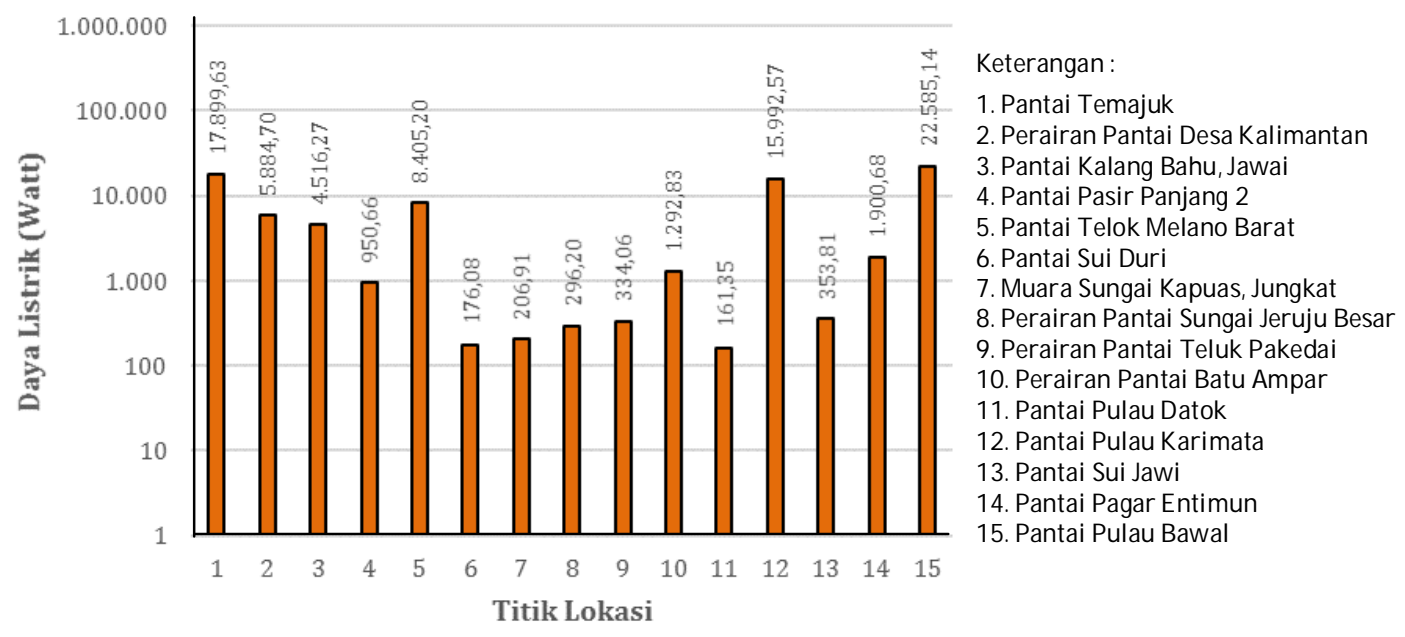

Gambar 5. Histogram rata-rata daya listrik kondisi peralihan I 


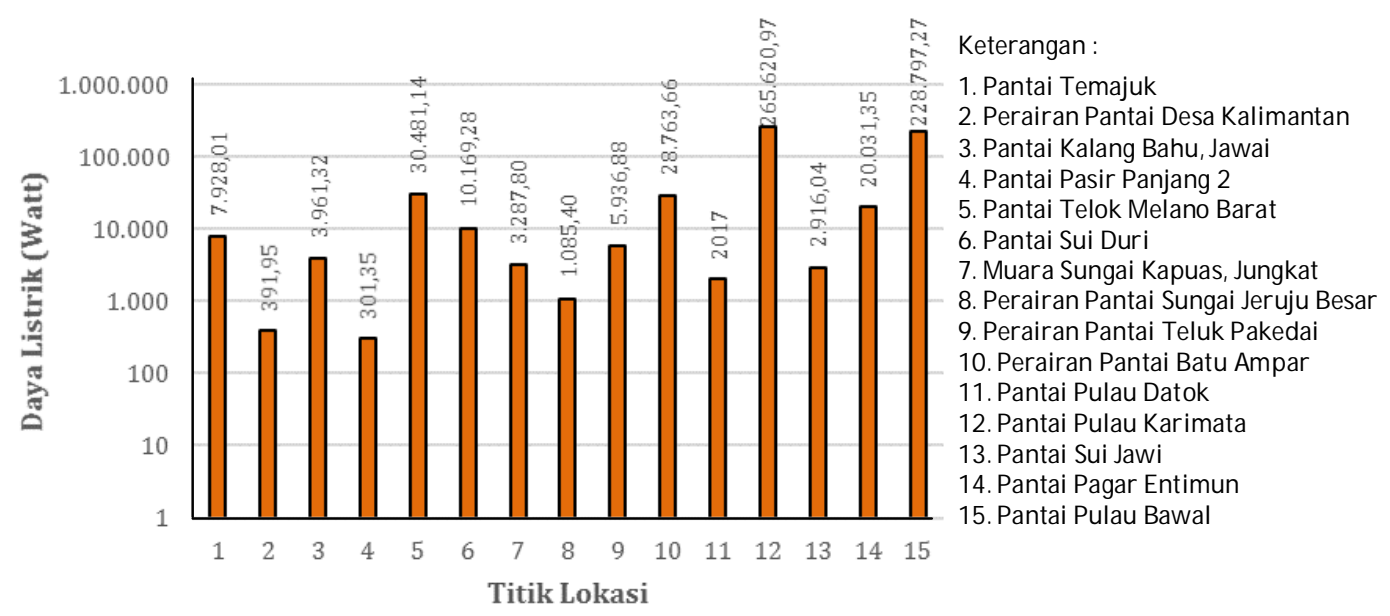

Gambar 6. Histogram rata-rata daya listrik musim timur

\subsubsection{Rata-rata Daya Listrik Sistem OWC pada Musim Timur}

Arah angin dominan pada musim timur (Juni-Juli-Agustus) di perairan pesisir Kalimantan Barat adalah angin tenggara hingga barat daya. Kecepatan angin yang bertiup pada musim timur di perairan pesisir Kalimantan Barat berkisar antara 1,802 s.d. $5,268 \mathrm{~m} / \mathrm{s}$. Nilai tinggi gelombang berkisar antara 0,054 s.d. 0,674 meter dan untuk periode gelombang berkisar antara 1,098 s.d. 7,637 detik. Kecepatan angin dan tinggi gelombang tertinggi berada di lokasi 15 (Pantai Pulau Bawal, Kab. Ketapang), kemudian kecepatan angin terendah berada di lokasi 3 (Pantai Kalang Bahu, Jawai, Kab. Sambas) dan tinggi gelombang terendah berada di lokasi 4 (Pantai Pasir Panjang 2, Kota Singkawang), sedangkan untuk periode gelombang tertinggi terletak di lokasi 12 (Pantai Pulau Karimata, Kab. Kayong Utara) dan periode gelombang terendah di lokasi 4 (Pantai Pasir Panjang 2, Kota Singkawang).

Rata-rata daya listrik di perairan pesisir Kalimantan Barat pada musim timur berkisar antara 301,35 s.d. 265.620,97 Watt (Gambar 6) dengan rata-rata daya listrik tertinggi berada di lokasi 12 (Pantai Pulau Karimata, Kab. Kayong Utara) dan rata-rata daya listrik terendah di lokasi 4 (Pantai Pasir Panjang 2, Kota Singkawang).

Lokasi 12 memiliki rata-rata daya listrik tertinggi dibandingkan dengan 14 tempat lainnya dikarenakan kecepatan angin dan tinggi gelombang di lokasi tersebut cukup besar, kemudian besar periode gelombang di lokasi tersebut merupakan periode terbesar dibandingkan tempat lainnya. Lokasi 12 memiliki fetch yang panjang dikarenakan tidak ada pulaupulau kecil yang menghalangi pembentukan fetch, sehingga menghasilkan tinggi dan periode gelombang yang besar pula. Sedangkan rata-rata daya listrik terendah berada di lokasi 4 , hal ini dikarenakan tinggi dan periode gelombang terendah berada di lokasi tersebut.

\subsubsection{Rata-rata Daya Listrik Sistem OWC pada Kondisi Peralihan II}

Arah angin dominan pada kondisi peralihan II (September-Oktober-Nopember) di perairan pesisir Kalimantan Barat adalah angin tenggara hingga barat daya sama seperti yang terjadi pada musim timur. Kecepatan angin yang bertiup pada kondisi peralihan II di perairan pesisir Kalimantan Barat berkisar antara 0,966 s.d. $4,603 \mathrm{~m} / \mathrm{s}$. Nilai tinggi gelombang berkisar antara 0,030 s.d. 0,548 meter dan untuk periode gelombang berkisar antara 0,966 s.d. 6,815 detik. Kecepatan angin dan tinggi gelombang tertinggi berada di lokasi 15 (Pantai Pulau Bawal, Kab. Ketapang) kemudian kecepatan angin dan tinggi gelombang terendah berada di lokasi 3 (Pantai Kalang Bahu, Jawai, Kab. Sambas) sedangkan untuk periode gelombang tertinggi terletak di lokasi 12 (Pantai Pulau Karimata, Kab. Kayong Utara) dan periode gelombang terendah di lokasi 4 (Pantai Pasir Panjang 2, Kota Singkawang).

Rata-rata daya listrik di perairan pesisir Kalimantan Barat pada kondisi peralihan II berkisar antara 139,64 s.d. 164.495,99 Watt (Gambar 7) dengan rata-rata daya listrik tertinggi berada di lokasi 15 (Pantai Pulau Bawal, Kab. Ketapang) dan rata-rata daya listrik terendah di lokasi 4 (Pantai Pasir Panjang 2, Kota Singkawang).

Lokasi 15 memiliki rata-rata daya listrik tertinggi dibandingkan dengan 14 tempat lainnya dikarenakan kecepatan angin dan tinggi gelombang yang tertinggi berada di lokasi tersebut. Lokasi 15 memiliki fetch yang panjang dikarenakan tidak ada pulau-pulau kecil yang menghalangi pembentukan fetch, karena berbatasan langsung dengan Laut Jawa. Kemudian rata-rata daya listrik terendah berada di lokasi 4 hal ini dikarenakan lokasi 4 memiliki periode terendah dibandingkan tempat lainnya. 


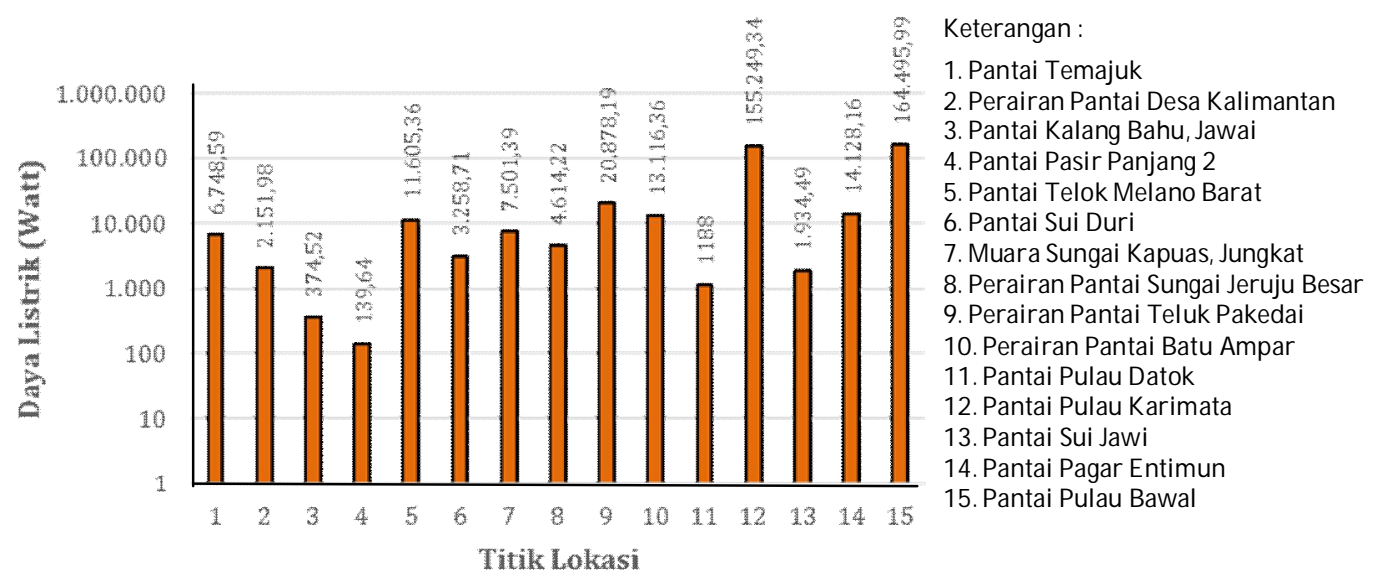

Gambar 7. Histogram rata-rata daya listrik kondisi peralihan II

\subsubsection{Daya Listrik Tertinggi dan Terendah Sistem OWC}

Daya listrik tertinggi berada di lokasi 12 (Pantai Pulau Karimata, Kab. Kayong Utara) pada musim barat dengan nilai sebesar 831.370,47 Watt (Gambar 8). Sedangkan daya listrik terendah berada di lokasi 11 (Pantai Pulau Datok, Kab. Kayong Utara) pada kondisi peralihan I dengan nilai sebesar 0,007 Watt (Gambar 9).
Lokasi 12 memiliki daya listrik tertinggi pada musim barat dikarenakan kecepatan angin, tinggi gelombang dan periode gelombang di lokasi tersebut cukup besar dan panjang fetch pada lokasi tersebut cukup besar dikarenakan tidak ada pulau-pulau kecil yang menjadi penghalang tebentuknya fetch. Sedangkan daya listrik terendah berada di lokasi 11 pada kondisi peralihan I dikarenakan kecepatan angin, tinggi gelombang dan periode gelombang di lokasi tersebut rendah dan fetch yang terbentuk juga kecil dikarenakan banyak terhalang oleh daratan.

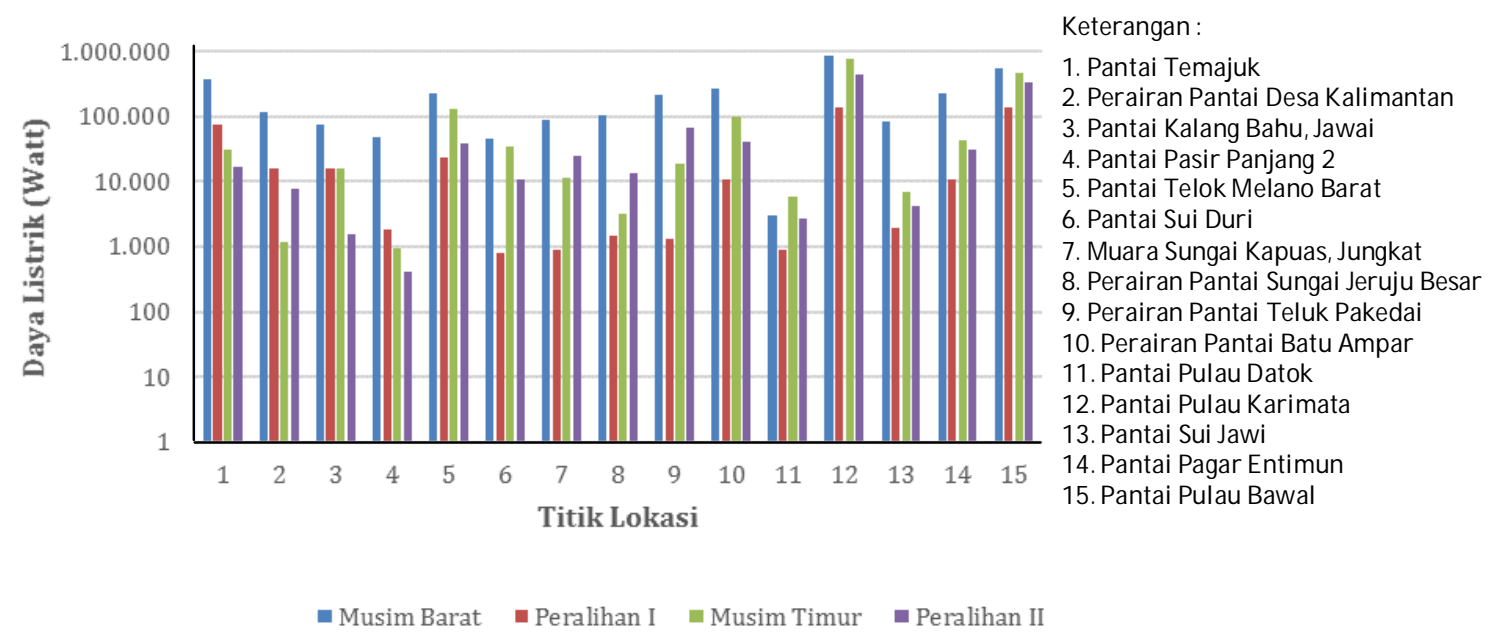

Gambar 8. Histogram daya listrik tertinggi tiap-tiap lokasi 


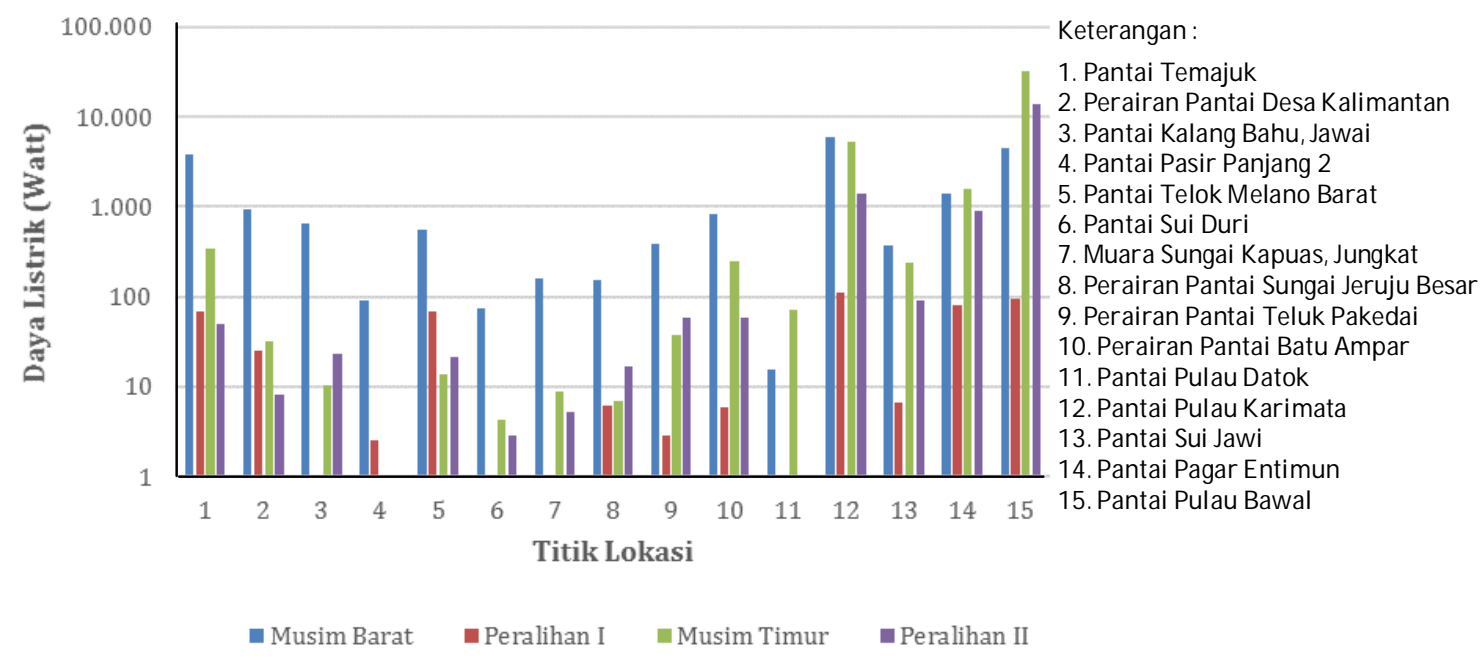

Gambar 9. Histogram daya listrik terendah tiap-tiap lokasi

\section{Kesimpulan}

Berdasarkan daya listrik yang telah dikaji, lokasi yang berpotensi besar menghasilkan daya listrik adalah Pantai Temajuk Kab. Sambas, Pantai Pulau Karimata Kab. Kayong Utara dan Pantai Pulau Bawal Kab. Ketapang. Daya listrik tertinggi berada di Pantai Pulau Karimata, Kab. Kayong Utara pada musim barat dengan nilai sebesar 831.370,47 Watt.

\section{DAFTAR PUSTAKA}

[1] Muchlis, M., \& Permana, A. D. (2006). Proyeksi Kebutuhan Listrik PLN di Indonesia Tahun 2003 s.d. 2020. Dalam Pengembangan Sistem Kelistrikan Nasional Dalam Menunjang Pembangunan Nasional Jangka Panjang (hal. 19-29). Jakarta: Pusat Pengkajian dan Penerapan Teknologi Konversi dan Konservasi Energi, BPPT.

[2] Mardiansyah, L. A., Ismanto, A., \& Setyawan, W. B. (2014). Kajian Potensi Gelombang Laut Sebagai Sumber Energi Alternatif Pembangkit Listrik Tenaga Gelombang Laut (PLTGL) dengan Sistem Oscilatting Water Column (OWC) di Perairan Pantai Bengkulu. JURNAL OSEANOGRAFI , III, 328-337.

[3] Wijaya, I. W. A. (2010). Pembangkit Listrik Tenaga Gelombang Laut Menggunakan Teknologi Oscillating Water Column di Perairan Bali. Teknologi Elektro, IX, 165174.

[4] European Center for Medium Range Forecast (ECMWF). Era Interim, Monthly Means of Daily Means. Dipetik Mei 10, 2015, dari http:// www.apps.ecmwf.int/ datasets/
[5] Triatmodjo, B. (1999). Teknik Pantai. Yogyakarta: Beta Offset.

[6] Jumarang, M. I. (1999). Studi Karakteristik Oseanografi Pantai untuk Penanaman Kembali Mangrove di Pantai Siwa Kabupaten Wajo. Makassar: Universitas Hasanuddin (Skripsi).

[7] Asosiasi Energi Laut Indonesia (ASELI). Pemanfaatan Energi Laut 1 : Ombak. Dipetik Juni 6, 2015, dari http:/ / www. aseli.co/

[8] Departement of Naval Architecture and Marine Enginering, University of Michigan. (2008). Wave Energy Conversions. USA.

[9] Utami, S. R. (2010). Studi Potensi Pembangkit Listrik Tenaga Gelombang Laut dengan Menggunakan Sistem Oscillating Water Column (OWC) di Tiga Puluh Wilayah Kelautan Indonesia. Depok: Universitas Indonesia (Skripsi).

[10] Murdani, E. (2007). Studi Karakteristik Fisik Gelombang Perairan Pulau Lemukutan Kabupaten Bengkayang. Pontianak: Universitas Tanjungpura (Skripsi). 